УДК 614.841:536.46

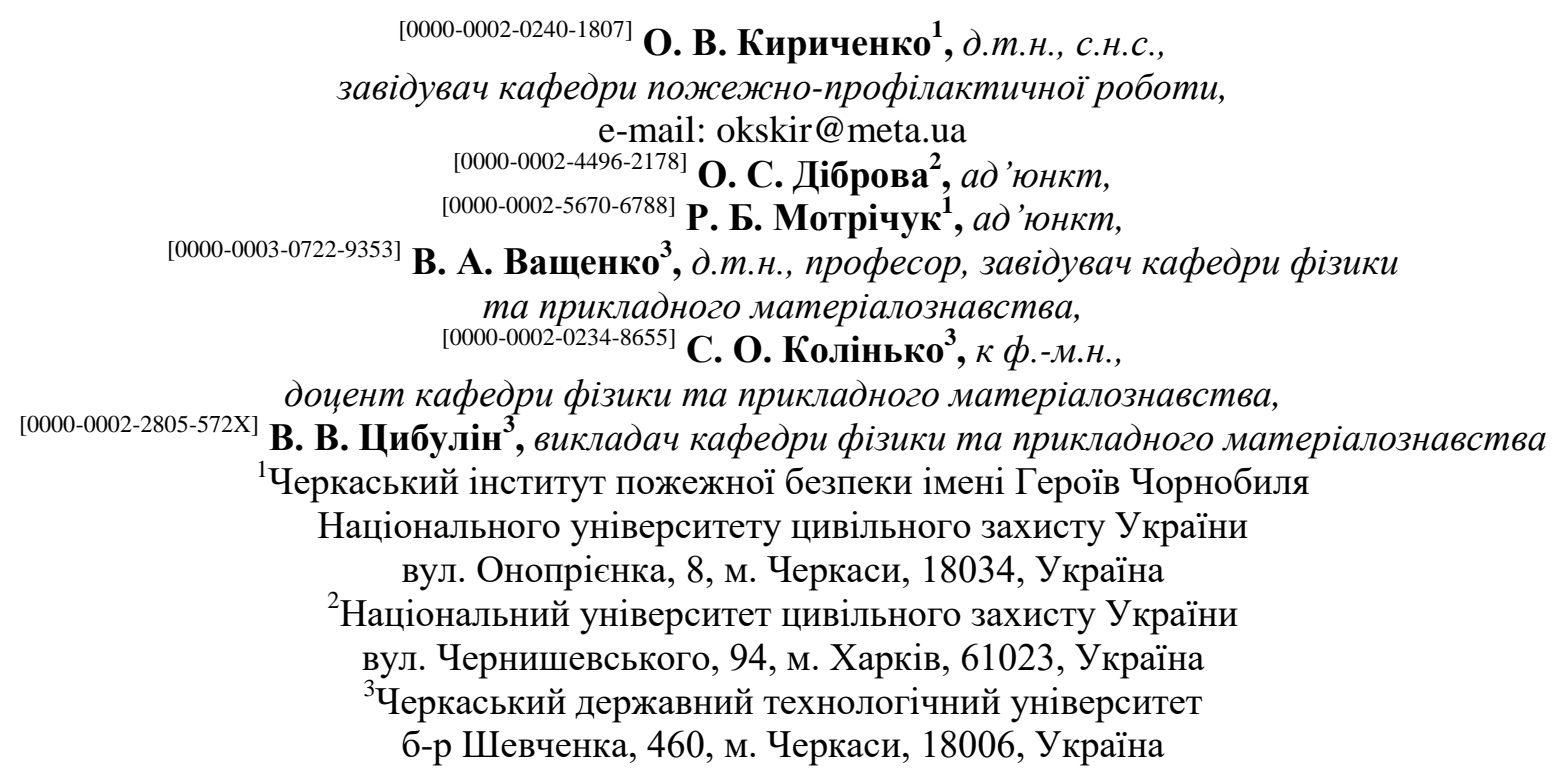

\title{
ДОСЛІДЖЕННЯ ВПЛИВУ МІЦНОСТІ ЗАРЯДІВ ПІРОТЕХНІЧНИХ НІТРАТНО- МЕТАЛЕВИХ СУМІШЕЙ НА ПОЖЕЖНУ БЕЗПЕКУ ВИРОБІВ НА ЇХ ОСНОВІ
}

В результаті проведених експериментальних досліджень встановлено, що порушення міцності поверхневих шарів піротехнічних нітратно-металевих сумішей призводить до передчасного пожежовибухонебезпечного спращьовування виробів на їх основі в умовах зовнішніх термічних дій. Отримано нові дані про вплив технологічних параметрів зразків сумішей (співвідномення та дисперсності компонентів, коефіиієнта їх ущільнення, природи нітратовмісного окиснювача й органічної добавки, тиску та напрямку пресування, часу витримки, висоти та діаметра зразків) на межу їх мічності.

Ключові слова: піротехнічна суміш, мічність, пожежна безпека.

Вступ. Загальнопромислові піротехнічні вироби (запалювальні, освітлювальні та сигнальні патрони та снаряди, трасувальні засоби, помилкові теплові цілі тощо) на основі нітратно-металевих сумішей (ущільнені суміші 3 порошків металевих пальних (Al, Mg, сплав AM, Ті та ін.) і нітратовмісних окиснювачів $\left(\mathrm{NaNO}_{3}, \mathrm{KNO}_{3}, \mathrm{Ba}\left(\mathrm{NO}_{3}\right)_{2}, \mathrm{Sr}\left(\mathrm{NO}_{3}\right)_{2}\right.$ та ін.) при ïx зберіганні, транспортуванні та застосуванні можуть піддаватися зовнішнім екстремальним впливам (наприклад, при пожежі у складських приміщеннях, де зберігаються вироби, в умовах їх транспортування при займанні близько розташованих об'єктів, а також в умовах пострілу та польоту виробів при їх запусках тощо [1-12]). Це призводить, в першу чергу, до втрати міцності зарядів сумішей (наприклад, у ï поверхневих шарах з'являються тріщини, відколи, локальні порожнини тощо), які викликають передчасне займання сумішей та вибухонебезпечний розвиток їх горіння в умовах зовнішніх впливів (наприклад, різке прискорення процесу горіння сумішей уздовж тріщин у локальних порожнинах та ін. за рахунок інтенсивного розкладання нітратовмісних окиснювачів).

В результаті відбуваються пожежонебезпечні руйнування виробів, які супроводжуються проявом різних чинників пожежі (полум'я або високотемпературний струмінь продуктів згоряння, залишки розжарених корпусів виробів і частин зарядів сумішей тощо (рисунок 1)).

Слід зазначити, що у багатьох випадках передчасні вибухонебезпечні спрацьовування піротехнічних виробів мають катастрофічні наслідки, оскільки практично непереборні складності виникають при гасінні зарядів сумішей, що спалахнули, внаслідок того, що процес їх займання та горіння здійснюється за рахунок власного окиснювача без участі кисню навколишнього повітря, а температури продуктів згоряння та вміст у них високотемпературного конденсату є вельми високими [13-18]. 


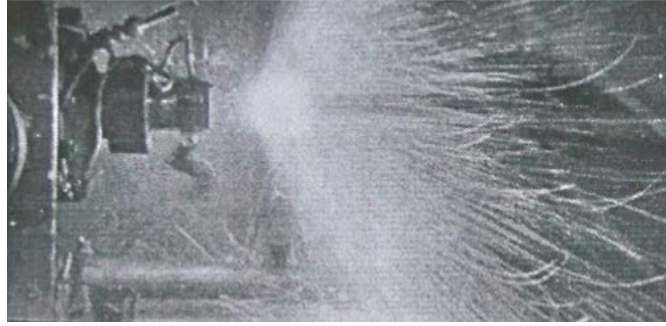

1

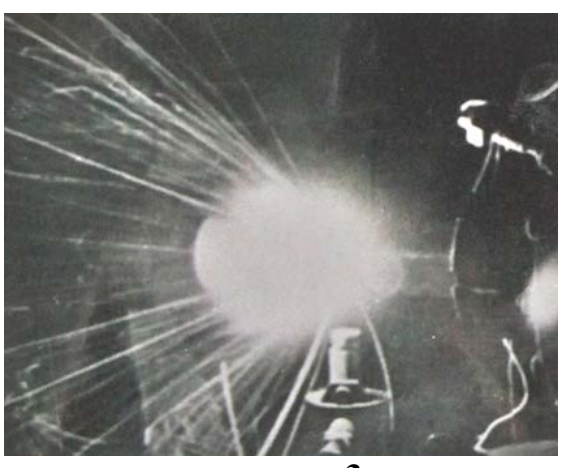

3

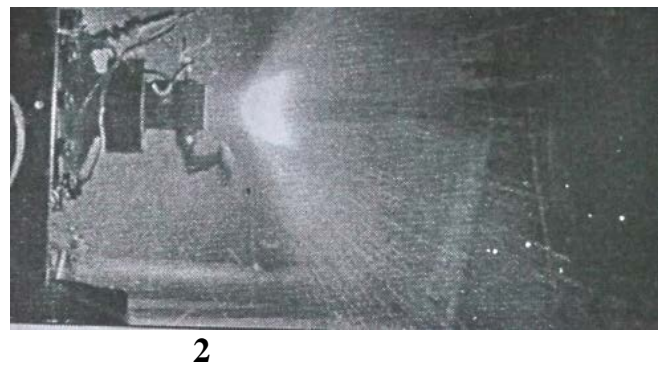

a)

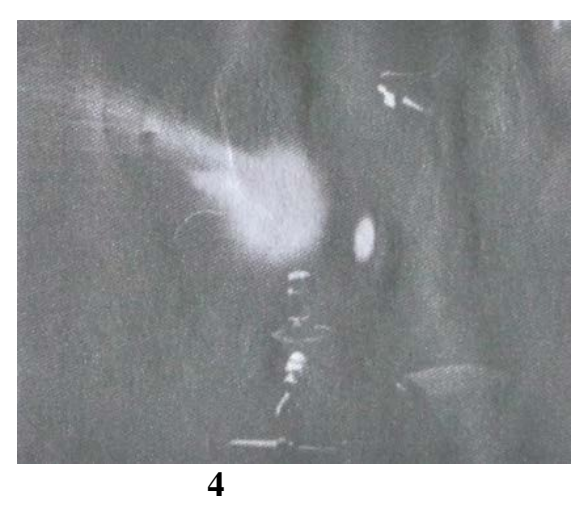

б)

1, 3 - суміші $з$ надлишком металевого пального; 2, 4 - суміші з надлишком окиснювача

Рисунок 1 - Кінокадри процесів передчасного спрацьовування та пожежонебезпечного руйнування освітлювальних виробів (склад білого вогню) на основі сумішей $\mathrm{NaNO}_{3}+\mathrm{AM}(a)$ та ІЧ-випромінювачів W111A, В на основі сумішей Вa( $\left.\mathrm{NO}_{3}\right)_{2}+\mathrm{Mg}(\sigma)$ при наявності поверхневих руйнувань їх зарядів

Тому практичне значення мають способи попередження виникнення пожежонебезпечних руйнувань виробів у випадку впливу зовнішніх дій. При цьому вони мають базуватися на науково-обгрунтованих методах визначення впливу значень параметрів зовнішніх дій і технологічних параметрів зарядів сумішей на граничні значення пружних напружень $\left(\sigma_{n}^{*}\right.$, Па) у поверхневих шарах зарядів сумішей, перевищення яких призводить до поверхневих руйнувань та передчасних пожежонебезпечних руйнувань виробів. Нині питанням забезпечення пожежної безпеки при виготовленні, зберіганні, транспортуванні та застосуванні піротехнічних виробів присвячено велику кількість досліджень як в Україні, так і за кордоном [19-26]. При цьому, якщо властивості сировини та технології виготовлення піротехнічних сумішей вивчені достатньо добре, то вплив різних технологічних параметрів (співвідношення компонентів та їх дисперсності, коефіцієнта ущільнення, діаметра заряду тощо) на їх міцність вивчені недостатньо. Для досліджуваних нітратнометалевих сумішей, що $є$ основою широко використовуваних піротехнічних виробів, вплив різних технологічних параметрів на міцність зарядів сумішей, а отже, на пожежонебезпечне руйнування виробів, не досліджено.

Тому метою роботи $\epsilon$ встановлення закономірностей впливу технологічних параметрів піротехнічних нітратно-металевих сумішей на їх міцність та пожежну безпеку виробів.

Результати досліджень та їх аналіз. Як зразки піротехнічних нітратно-металевих сумішей (ПНМС) використовувались ущільнені суміші з порошків металів (Al, Mg, сплав AM, Ті та ін.), нітратовмісних окиснювачів $\left(\mathrm{NaNO}_{3}, \mathrm{KNO}_{3}, \mathrm{Ba}\left(\mathrm{NO}_{3}\right)_{2}, \operatorname{Sr}\left(\mathrm{NO}_{3}\right)_{2}\right.$ та ін.) та добавок органічних речовин (бутилкаучук, тіокол, нітроплівка, смола 214 та ін.), які виготовлялися за технологією, прийнятою у піротехнічному виробництві $[6-9,19]$. Усі випробування зразків ПНМС проводилися на стандартному піротехнічному обладнанні [10, 11, 19], при цьому відносна похибка результатів досліджень не перевищувала $5 . .10 \%$.

В результаті проведених досліджень було встановлено, що зразки ПНМС мають анізотропність міцності, тобто іiі залежність від напрямку дії навантаження (таблиця 1).

( ) О. В. Кириченко, О. С. Діброва, Р. Б. Мотрічук, В. А. Ващенко, С. О. Колінько, В. В. Цибулін, 2019 DOI: 10.24025/2306-4412.3.2019.176874 
3 таблиці 1 видно, що міцність зразків на розтяг нижча в напрямку пресування, а їх міцність на стиснення в напрямку пресування, навпаки, вища. При цьому різниця у міцності зразків у різних напрямках на стиснення менша, ніж на розтяг.

Таблиця 1 - Міцнісні характеристики пресованих зразків

\begin{tabular}{|c|c|c|c|c|c|}
\hline \multirow[b]{2}{*}{ Компоненти ПНМС } & \multicolumn{2}{|c|}{$\begin{array}{c}\text { Межа міцності } \\
\text { на стиснення, } 10^{5} \text { Па }\end{array}$} & \multicolumn{2}{|c|}{$\begin{array}{c}\text { Межа міцності } \\
\text { на розтяг, } 10^{5} \text { Па }\end{array}$} & \multirow[t]{2}{*}{$\begin{array}{c}\text { Коефіцієнт } \\
\text { ущільнення, } K_{y}\end{array}$} \\
\hline & 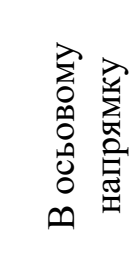 & 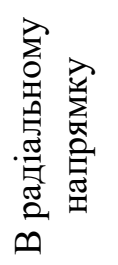 & 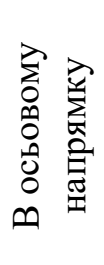 & 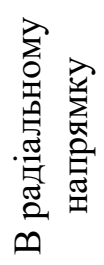 & \\
\hline $\begin{array}{c}\text { МПФ - } 2-50 \% \\
\mathrm{NaNO}_{3}-50 \%\end{array}$ & 1280 & 630 & 30 & 48 & $0,96-0,98$ \\
\hline $\begin{array}{l}\mathrm{M} Ф \Phi-2-50 \% \\
\mathrm{Ba}\left(\mathrm{NO}_{3}\right)_{2}-50 \%\end{array}$ & 1093 & 370 & 13,2 & 46 & $0,96-0,98$ \\
\hline $\begin{array}{c}\text { ПАM - } 2-50 \% \\
\mathrm{NaNO}_{3}-50 \%\end{array}$ & 144 & 59 & 1,7 & 14,1 & $0,91-0,92$ \\
\hline
\end{tabular}

Примітка. Розміри зразків, отриманих пресуванням: $10^{-3} \times 10^{-3} \times 10^{-3}$ м. Середній розмір частинок (дисперсність) металевих порошків: МПФ - 2 (порошок магнієвий) - 182 мкм; ПАМ - 2 (порошок сплаву АМ) - 227 мкм. Порошки окиснювачів мають дисперсність 100 мкм.

Встановлено, що межа міцності на стиснення $\left(\sigma_{n}^{c m}\right.$, Па) пресованих ПНМС зростає 3 підвищенням тиску пресування $(P$, Па); при цьому характер функції $\sigma_{n}^{c m}=f(P)$ залежить від технологічних параметрів (співвідношення компонентів у суміші та їх дисперсності, коефіцієнта ущільнення, форми та розмірів зарядів тощо) і змінюється від експоненціального до лінійного.

Отримано, що міцність пресованих ПНМС зростає $з$ підвищенням їх коефіцієнта ущільнення тільки для деяких сумішей. В загальному випадку коефіцієнт ущільнення та міцність різних ПНМС є незалежними характеристиками - менш густа пресована суміш може бути більш міцною, та навпаки.

Встановлено, що межа міцності окиснювачів, спресованих практично до густини монолітного матеріалу (тиск пресування $5 \cdot 10^{8} \ldots 6 \cdot 10^{8}$ Па) значно нижча міцності пресованих металевих порошків (за винятком сплавів $\mathrm{AM})$ і становить: для $\operatorname{Sr}\left(\mathrm{NO}_{3}\right)_{2}-$ $8 \cdot 10^{6}$ Па; для $\mathrm{NaClO}_{4}-5,5 \cdot 10^{7}$ Па; для $\mathrm{KNO}_{3}-$ $5,8 \cdot 10^{7}$ Па; для $\mathrm{NaNO}_{3}-8,5 \cdot 10^{7}$ Па.

Залежності межі міцності на стиснення для пресованих зразків окиснювачів та магнієвого порошку МПФ - 3 (135 мкм) показано на рисунку 2.

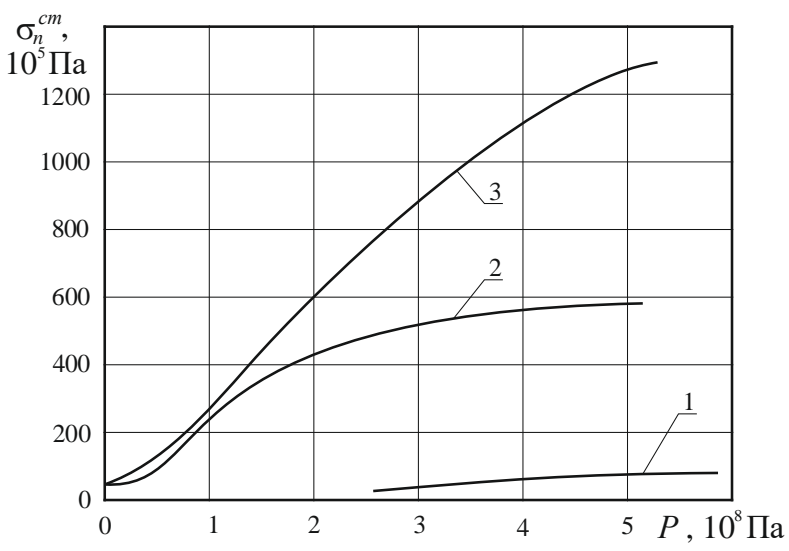

$1-\mathrm{Sr}\left(\mathrm{NO}_{3}\right)_{2}, d=9,9 \cdot 10^{-3} \mathrm{M} ; 2-\mathrm{KNO}_{3}, d=9,8 \cdot 10^{-3} \mathrm{M} ;$ $3-\mathrm{M \Pi \Phi -3,} d=1,5 \cdot 10^{-2} \mathrm{M}$

Рисунок 2 - Залежність межі міцності на стиснення від тиску пресування для компонентів ПНМС $(h / d=1,3 . . .1,6$; $h, d$ - відповідно висота запресовування і діаметр зразка)

Встановлено, що з підвищенням вмісту порошку металу у ПНМС міцність ії зразків (таблеток), яка оцінюється за зусиллям роздавлювання, монотонно зростає, наближаючись до одного й того ж значення (таблиця 2). 
Таблиця 2 - Залежність межі міцності таблеток суміші Ti + окиснювач від вмісту металу ( $\kappa_{y}=0,85$, дисперсність окиснювача - 45 мкм, порошок титану - ПТМ (45 мкм)

\begin{tabular}{|c|c|c|c|c|}
\hline Окиснювач & $h / r$ & Вміст у суміші, \% & $\begin{array}{c}\text { Тиск пресування } \\
P=8,5 \cdot 10^{4} \text { Па }\end{array}$ & $\begin{array}{c}\text { Межа міцності, } \\
10^{5} \text { Па }\end{array}$ \\
\hline \multirow{2}{*}{$\mathrm{NaNO}_{3}$} & - & 0 & 1200 & 22,4 \\
& 4 & 14 & 1200 & 24,0 \\
& 2 & 77 & 700 & 59,6 \\
\hline \multirow{2}{*}{$\mathrm{KNO}_{3}$} & - & 0 & 1600 & 20,8 \\
& 4 & 15 & 1500 & 21,4 \\
& 2 & 77 & 7200 & 60,5 \\
\hline \multirow{3}{*}{$\mathrm{Ba}\left(\mathrm{NO}_{3}\right)_{2}$} & - & 0 & 2000 & 5,8 \\
& 2 & 10 & 3000 & 8,1 \\
\hline \multirow{2}{*}{$\mathrm{Sr}\left(\mathrm{NO}_{3}\right)_{2}$} & - & 80 & 9000 & 64,9 \\
& 2 & 11 & 2000 & 3,9 \\
& 2 & 71 & 2400 & 62,4 \\
\hline
\end{tabular}

Примітка. Величина $h / r$ - відношення товщини таблетки до іiї радіуса.

Було проведено також дослідження залежності порівняльної міцності пресованих таблеток ПНМС від таких чинників, як природа окиснювача, співвідношення компонентів, їх дисперсність, спосіб отримання порошку металевого пального, наявність органічних добавок. В результаті було встановлено, що порівняльна міцність таблеток 3 подвійних сумішей титан + неорганічний окиснювач, що визначається за зусиллям роздавлювання, також, як і в циліндричних зразках, зростає 3 підвищенням тиску пресування, й, отже, коефіцієнта ущільнення. У таблицях 3, 4 наведено вплив на порівняльну міцність таблеток природи окиснювача, співвідношення компонентів і температури нагріву. Встановлено, що, незалежно від коефіцієнта ущільнення, природи окиснювача та температури нагріву, 3 підвищенням вмісту металу у суміші міцність збільшується.

Таблиця 3 - Відносна міцність таблеток залежно від природи окиснювача та співвідношення компонентів при різних значеннях коефіціснта ущільнення $K_{y}$

\begin{tabular}{|c|c|c|c|}
\hline \multirow{2}{*}{ Окиснювач } & \multirow{2}{*}{ Масова частка Ті у суміші, \% } & \multicolumn{2}{|c|}{ Зусилля роздавлювання, $\mathrm{H}$} \\
\cline { 2 - 4 } & 30 & $K_{y}=0,7$ & $K_{\mathrm{y}}=0,9$ \\
\hline \multirow{3}{*}{$\mathrm{KNO}_{3}$} & 38 & 61,8 & 308,0 \\
& 47 & 103,0 & 430,6 \\
& 56 & 124,6 & 486,6 \\
& 65 & 119,7 & 516,0 \\
& 32 & 147,1 & 567,0 \\
\hline \multirow{3}{*}{$\mathrm{NaNO}_{3}$} & 41 & 74,5 & 393,4 \\
& 50 & 89,3 & 438,5 \\
& 58 & 120,7 & 484,6 \\
& 67 & 133,4 & 523,8 \\
$\mathrm{Sr}\left(\mathrm{NO}_{3}\right)_{2}$ & 29 & 157,9 & 586,6 \\
& 37 & 0 & 194,2 \\
& 45 & 26,5 & 240,3 \\
& 54 & 52,0 & 291,3 \\
& 62 & 97,5 & 355,1 \\
& 30 & 3,2 & 409,1 \\
\hline $\mathrm{Ba}\left(\mathrm{NO}_{3}\right)_{2}$ & 38 & 32,4 & 232,5 \\
& 47 & 58,9 & 260,9 \\
& 56 & 89,3 & 340,4 \\
& 65 & 106,9 & 336,5 \\
& & & 460,1 \\
\hline
\end{tabular}

( ) О. В. Кириченко, О. С. Діброва, Р. Б. Мотрічук, В. А. Ващенко, С. О. Колінько, В. В. Цибулін, 2019 DOI: $10.24025 / 2306-4412.3 .2019 .176874$ 
Таблиця 4 - Вплив на відносну міцність таблеток вмісту титану у суміші та природи окиснювача при різних температурах нагріву $\left(\kappa_{y}=0,85\right)$

\begin{tabular}{|c|c|c|c|c|}
\hline \multirow{3}{*}{ Окиснювач } & \multirow{2}{*}{$\begin{array}{c}\text { Масова частка Ti } \\
\text { у суміші, \% }\end{array}$} & \multicolumn{3}{|c|}{ Зусилля роздавлювання $(H)$} \\
\cline { 3 - 5 } & 32 & 333 & 293 & 213 \\
\hline \multirow{5}{*}{$\mathrm{NaNO}_{3}$} & 41 & 339,4 & 363,0 & 394,4 \\
& 50 & 367,9 & 338,4 & 415,0 \\
& 58 & 399,3 & 412,0 & 426,7 \\
& 67 & 426,7 & 451,3 & 451,3 \\
& 30 & 320,8 & 332,5 & 464,0 \\
\hline & 38 & 329,6 & 345,3 & 373,1 \\
$\mathrm{KNO}_{3}$ & 47 & 358,1 & 367,9 & 389,4 \\
& 56 & 383,6 & 417,9 & 428,7 \\
& 65 & 419,9 & 439,5 & 443,4 \\
\hline & 29 & 140,3 & 155,0 & 161,9 \\
& 37 & 169,7 & 182,5 & 187,4 \\
& 45 & 186,4 & 208,0 & 219,7 \\
& 54 & 235,4 & 248,2 & 260,0 \\
& 62 & 285,5 & 307,0 & 317,8 \\
\hline \multirow{5}{*}{} & 30 & 169,7 & 181,5 & 201,1 \\
& 38 & 183,4 & 186,4 & 215,8 \\
& 47 & 218,8 & 226,6 & 235,4 \\
& 56 & 258,0 & 299,2 & 313,9 \\
& 65 & 321,8 & 340,4 & 353,2 \\
\hline
\end{tabular}

При цьому ступінь впливу зміни вмісту порошку титану на міцність таблеток помітно залежить від природи окиснювача (таблиця 5).

Показано, що у сумішей, які містять $\mathrm{Sr}\left(\mathrm{NO}_{3}\right)_{2}$, міцність таблеток сильно залежить від вмісту титану, у сумішей, які містять $\mathrm{NaNO}_{3}$, - слабо. Зі зниженням температури нагріву, незалежно від вмісту у суміші титану та природи окиснювача, міцність таблеток зростає. Однак зі збільшенням вмісту титану, незалежно від природи окиснювача, ступінь впливу температури нагріву послаблюється (таблиця 6).

Таблиця 5 - Вплив вмісту порошку Ті у сумішах з різними окиснювачами на зміну міцності таблеток при різних температурах нагріву $\left(K_{y}=0,85\right)$

\begin{tabular}{|c|c|c|c|c|}
\hline \multirow{2}{*}{ Окиснювач } & \multirow{2}{*}{$\varphi_{\max } / \varphi_{\min }$} & \multicolumn{3}{|c|}{$P_{\max } / P_{\min }$ при температурах нагріву, $K$} \\
\cline { 3 - 5 } & 2,1 & 333 & 293 & 213 \\
\hline $\mathrm{NaNO}_{3}$ & 2,2 & 1,2 & 1,3 & 1,2 \\
\hline $\mathrm{KNO}_{3}$ & 2,1 & 2,3 & 1,3 & 1,3 \\
\hline $\mathrm{Sr}\left(\mathrm{NO}_{3}\right)_{2}$ & 2,2 & 1,9 & 1,3 & 2,0 \\
\hline $\mathrm{Ba}\left(\mathrm{NO}_{3}\right)_{2}$ & &
\end{tabular}

Примітка. $\varphi_{\max } / \varphi_{\min }$ - відношення максимального вмісту Ті у суміші до мінімального;

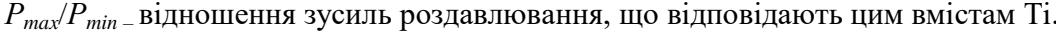

Таблиця 6 - Вплив температури нагріву на відносну міцність таблеток при різному вмісті титану у сумішах з різними окиснювачами

\begin{tabular}{|c|c|c|}
\hline \multirow{2}{*}{ Окиснювач } & \multicolumn{2}{|c|}{$\frac{\left(P_{213 K^{-}} P_{333 K}\right) \cdot 100}{P_{213 K}}$} \\
\cline { 2 - 3 } & $\varphi_{\min }$ & $\varphi_{\max }$ \\
\hline $\mathrm{Ba}\left(\mathrm{NO}_{3}\right)_{2}$ & 18 & 10 \\
\hline $\mathrm{Sr}\left(\mathrm{NO}_{3}\right)_{2}$ & 15 & 11 \\
\hline $\mathrm{NaNO}_{3}$ & 14 & 9 \\
\hline $\mathrm{KNO}_{3}$ & 11 & 6 \\
\hline
\end{tabular}

( ) О. В. Кириченко, О. С. Діброва, Р. Б. Мотрічук, В. А. Ващенко, С. О. Колінько, В. В. Цибулін, 2019 DOI: 10.24025/2306-4412.3.2019.176874 
На міцність таблеток впливає також дисперсність окиснювача та титану. Як видно 3 таблиці 7, зі зменшенням розміру частинок як титану, так і окиснювача міцність суміші зростає. $\left.\kappa_{y}=\mathbf{0 , 8 5}\right)$

Таблиця 7 - Вплив на міцність таблеток дисперсності компонентів сумішей $(\alpha=\mathbf{0 , 8 0}$,

\begin{tabular}{|c|c|c|c|c|c|c|c|c|}
\hline \multirow{2}{*}{ Суміш } & \multicolumn{3}{|c|}{$\begin{array}{c}\text { 3усилля роздавлювання }(H) \\
\text { при фракціях окиснювача (мкм) } \\
\text { (порошок титану ПТМ) }\end{array}$} & \multicolumn{3}{|c|}{$\begin{array}{c}\text { Зусилля роздавлювання }(H) \\
\text { при фракціях титану (мкм) } \\
\text { (окиснювач фракції - 180 мкм) }\end{array}$} \\
\cline { 2 - 9 } & -45 & $\begin{array}{r}+45 \\
-100\end{array}$ & $\begin{array}{r}+100 \\
-140\end{array}$ & $\begin{array}{r}+140 \\
-280\end{array}$ & -45 & $\begin{array}{r}+45 \\
-100\end{array}$ & $\begin{array}{r}+100 \\
-140\end{array}$ & $\begin{array}{r}+140 \\
-250\end{array}$ \\
\hline $\mathrm{KNO}_{3}+\mathrm{Ti}$ & 375,7 & 357,1 & 333,5 & 301,2 & 414,0 & 363,9 & 310,0 & 258,0 \\
\hline $\mathrm{Ba}\left(\mathrm{NO}_{3}\right)_{2}+\mathrm{Ti}$ & 248,2 & 233,5 & 182,5 & 156,0 & 274,7 & 238,4 & 209,9 & 171,7 \\
\hline
\end{tabular}

Таблиця 8 - Відносна міцність таблеток залежно від способу отримання титанового порошку ( $\alpha=0,80, \kappa_{y}=0,85$, дисперсність титану -45 мкм)

\begin{tabular}{|c|c|c|}
\hline \multirow{2}{*}{ Суміш } & \multicolumn{2}{|c|}{ Зусилля роздавлювання $(H)$} \\
\cline { 2 - 3 } & Гідридно-кальцієвий & Електролітичний \\
\hline $\mathrm{NaNO}_{3}+\mathrm{Ti}$ & 375,7 & 366,9 \\
\hline $\mathrm{Ba}\left(\mathrm{NO}_{3}\right)_{2}+\mathrm{Ti}$ & 248,2 & 257,0 \\
\hline
\end{tabular}

Встановлено, що ступінь збільшення міцності таблеток зі зміною дисперсності порошку титану практично не залежить від природи окиснювача. Так, міцність таблеток із сумішей $\mathrm{Ti}+\mathrm{NaNO}_{3}$ та $\mathrm{Ti}+\mathrm{Ba}\left(\mathrm{NO}_{3}\right)_{2}$ при зміні дисперсності порошку титану від (+ 140 - 250) мкм до (-45 мкм) зростає в $1,4 \ldots 1,6$ разу. При цьому підвищення міцності таблеток цих же сумішей при збільшенні дисперсності окиснювача також практично однакове: для суміші $\mathrm{Ti}+\mathrm{NaNO}_{3}-$ в 1,3 разу, для суміші $\mathrm{Ti}+\mathrm{Ba}\left(\mathrm{NO}_{3}\right)_{2}-$ в 1,4 разу.
При цьому від способу отримання титанового порошку міцність таблеток залежить дуже слабо (таблиця 8).

Таблиця 9 - Вплив природи та кількості органічних добавок на міцність таблеток 3 пресованих сумішей $\mathrm{Ti}+$ окиснювач

\begin{tabular}{|c|c|c|c|c|c|c|c|c|c|c|}
\hline \multirow{2}{*}{$\begin{array}{c}\text { Вихідна } \\
\text { суміш }\end{array}$} & \multicolumn{9}{|c|}{ Зусилля роздавлювання таблетки $(H)$ при введенні органічних добавок } \\
\cline { 2 - 11 } & \multicolumn{4}{|c|}{ Ідітол } \\
\cline { 2 - 11 } & 0 & 3 & 6 & 12 & 3 & 6 & 12 & 3 & 6 & 9 \\
\hline $\mathrm{Ti}+\mathrm{NaNO}_{3}$ & 338,4 & 453,2 & 483,6 & 497,4 & 461,1 & 500,3 & 516,0 & 456,2 & 497,4 & 509,1 \\
\hline $\mathrm{Ti}+\mathrm{Ba}\left(\mathrm{NO}_{3}\right)_{2}$ & 171,7 & 286,4 & 357,1 & 369,8 & 301,2 & 381,6 & 386,5 & 303,1 & 365,9 & 376,7 \\
\hline
\end{tabular}


Продовження таблиці 9

\begin{tabular}{|c|c|c|c|c|c|c|c|c|c|}
\hline \multirow{3}{*}{$\begin{array}{l}\text { Вихідна } \\
\text { суміш }\end{array}$} & \multicolumn{9}{|c|}{$\begin{array}{l}\text { Зусилля роздавлювання таблетки }(H) \text { при введенні органічних добавок } \\
\text { (мас. \%) }\end{array}$} \\
\hline & \multicolumn{3}{|c|}{ ПВХ } & \multicolumn{2}{|c|}{$\begin{array}{l}\text { Фторопласт } \\
\text { 32Л }\end{array}$} & \multicolumn{2}{|c|}{$\begin{array}{l}\text { Фторкаучук } \\
\text { СКФ-32 }\end{array}$} & \multicolumn{2}{|c|}{ Тіокол } \\
\hline & 3 & 6 & 9 & 6 & 12 & 6 & 12 & 6 & 12 \\
\hline $\mathrm{Ti}+\mathrm{NaNO}_{3}$ & 381,6 & 415,9 & 427,7 & 454,2 & 488,5 & 503,2 & 523,8 & 557,2 & 577,8 \\
\hline $\mathrm{Ti}+\mathrm{Ba}\left(\mathrm{NO}_{3}\right)_{2}$ & 266,8 & 284,5 & 295,3 & 358,1 & 385,5 & 377,7 & 415,0 & 439,5 & 458,1 \\
\hline \multirow{3}{*}{$\begin{array}{l}\text { Вихідна } \\
\text { суміш }\end{array}$} & \multicolumn{9}{|c|}{$\begin{array}{c}\text { Зусилля роздавлювання таблетки }(H) \text { при введенні органічних добавок } \\
\text { (мас. \%) }\end{array}$} \\
\hline & \multicolumn{3}{|c|}{ Бутилкаучук } & \multicolumn{3}{|c|}{$\begin{array}{l}\text { Гексахлорпара- } \\
\text { ксилол }\end{array}$} & \multicolumn{3}{|c|}{ Нітроплівка + смола 214} \\
\hline & \multicolumn{2}{|l|}{0} & 12 & 6 & \multicolumn{2}{|c|}{12} & $3+3$ & \multicolumn{2}{|c|}{$6+6$} \\
\hline $\mathrm{Ti}+\mathrm{NaNO}_{3}$ & \multicolumn{2}{|c|}{551,3} & 563,1 & 407,1 & \multicolumn{2}{|c|}{434,6} & 482,6 & \multicolumn{2}{|c|}{513,1} \\
\hline $\mathrm{Ti}+\mathrm{Ba}\left(\mathrm{NO}_{3}\right)_{2}$ & \multicolumn{2}{|c|}{442,4} & 464,0 & 294,3 & \multicolumn{2}{|c|}{307,0} & 382,6 & \multicolumn{2}{|c|}{420,8} \\
\hline
\end{tabular}

Отримано, що, незалежно від природи органічної добавки, істотне збільшення міцності таблеток досліджуваних сумішей спостерігається при введенні добавки в кількості до $6 \%$; подальше підвищення вмісту добавки підвищує міцність незначно.
Крім того, міцність пресованих сумішей залежить як від тиску пресування, так і від висоти запресовування, часу витримки при пресуванні, виду пресування. Вплив цих чинників показано у таблицях 10, 11 і на рисунку 3.

Таблиця 10 - Вплив висоти запресовування на межу міцності зразків сумішей на стиснення

\begin{tabular}{|c|c|c|c|c|c|c|}
\hline Склад суміші, \% & $\begin{array}{c}\text { Маса } \\
\text { суміші, } \\
10^{-3} \kappa \Gamma\end{array}$ & $\begin{array}{c}\text { Висота } \\
\text { запресову- } \\
\text { вання, } 10^{-3} \text { м }\end{array}$ & $\begin{array}{c}\text { Діаметр } \\
\text { зразка, } \\
10^{-3} \mathrm{M}\end{array}$ & 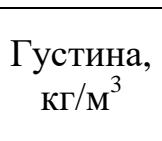 & $\begin{array}{c}\text { Тиск } \\
\text { пресування, } \\
10^{5} \text { Па }\end{array}$ & $\begin{array}{c}\text { Межа міцності } \\
\text { на стиснення } \\
\sigma_{n}^{c m}, 10^{5} \text { Па }\end{array}$ \\
\hline \multirow{7}{*}{$\begin{array}{lr}\mathrm{KNO}_{3} & (65) \\
\mathrm{Ва}\left(\mathrm{NO}_{3}\right)_{2} & (10) \\
\text { ПАМ - } & (8) \\
\text { Ідітол } & (17)\end{array}$} & 1,97 & 9,6 & 13,3 & 1460 & 981 & 103 \\
\hline & 3,51 & 17,9 & 13,3 & 1410 & 981 & 29 \\
\hline & 4,94 & 25,4 & 13,3 & 1400 & 1962 & 10 \\
\hline & 1,50 & 6,4 & 13,3 & 1690 & 1962 & 530 \\
\hline & 2,00 & 8,6 & 13,3 & 1670 & 1962 & 343 \\
\hline & 2,98 & 13,1 & 13,3 & 1630 & 1962 & 310 \\
\hline & 5,01 & 22,2 & 13,3 & 1620 & 1962 & 85 \\
\hline $\mathrm{Sr}\left(\mathrm{NO}_{3}\right)_{2}$ & 0,32 & 2,7 & 9,0 & 1900 & 1844 & 1545 \\
\hline МПФ -3 (43) & 0,54 & 4,1 & 9,0 & 2070 & 1844 & 863 \\
\hline $\mathrm{SrCO}_{3}$ & 1,02 & 8,1 & 9,0 & 1970 & 1844 & 398 \\
\hline Смола поліхлор- & 1,50 & 12,4 & 9,0 & 1910 & 1844 & 245 \\
\hline вінілова (6) & 1,79 & 15,6 & 9,0 & 1810 & 1844 & 167 \\
\hline Смола 311 (10) & 2,28 & 20,8 & 9,0 & 1800 & 1844 & 157 \\
\hline
\end{tabular}

Таблиця 11 - Вплив часу витримки $\tau$ при пресуванні на межу міцності на стиснення суміші складу: $\mathrm{KNO}_{3}(65 \%), \mathrm{Ba}\left(\mathrm{NO}_{3}\right)_{2}(10 \%)$, ПАМ - 4 (8 \%), ідітол (17 \%) (висота зразка $h=(1,3 \ldots 1,4) \cdot 10^{-2} \mathrm{м}$, діаметр $-1,33 \cdot 10^{-2}$ м, тиск пресування $-2 \cdot 10^{8}$ Па)

\begin{tabular}{|c|c|c|c|c|c|c|c|c|}
\hline$\tau, \mathrm{c}$ & 1 & 2 & 8 & 9 & 15 & 20 & 40 & 60 \\
\hline$\sigma_{n}^{c m}, 10^{5} \Pi \mathrm{a}$ & 163 & 170 & 191 & 198 & 226 & 219 & 232 & 209 \\
\hline
\end{tabular}




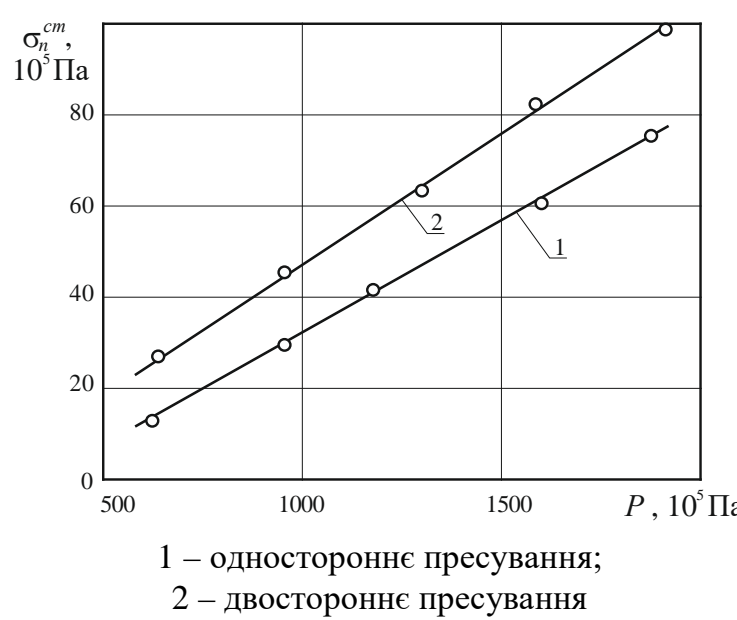

Рисунок 3 - Залежність межі міцності на стиснення суміші на основі МПФ - 2 (65 \%) та $\mathrm{NaNO}_{3}(30 \%)$ від виду пресування (зразки діаметром 9.10

Як видно з таблиць 10, 11 та рисунка 3, при підвищенні тиску пресування, зниженні висоти пресування, збільшенні часу витримки, застосуванні двостороннього пресування міцність сумішей збільшується.

При цьому величина приросту густини в широкому діапазоні тисків пресування аж до досягнення монолітних сумішей не залишається постійною, а 3 підвищенням тиску пресування зменшується, асимптотично наближаючись до нуля.

Встановлено також, що при перепресуванні сумішей (при підвищенні тиску пресування до значень $(1 \ldots 2) \cdot 10^{9}$ Па) ані істотного зміцнення, ані розупорядкування суміші не відбувається порівняно з сумішшю, отриманою при тиску, при якому досягається $\rho_{\max }$.

На закінчення слід відзначити, що вплив різних чинників на міцність пресованих сумішей можна пояснити за допомогою існуючих уявлень про міцнісні зв'язки, що утворюються в процесі пресування у результаті взаємодії стискаючих зусиль [8-10, 11].

У пресованих сумішах 3 хаотично розташованими частинками порошків металів та неорганічних речовин (наприклад окиснювача) міцнісні зв'язки можуть утворюватися на окремих контактах суміжних частинок метал - метал, метал - окиснювач та окиснювач окиснювач.

Утворення міцнісних зв'язків на контактах частинок метал-метал можливе при їх відносному переміщенні та деформації.
В результаті тертя, що виникає при взаємному переміщенні суміжних частинок металу, можливе як контактне налипання, так i приварювання частинок. При цьому міцність приварювання є настільки великою, що процес руйнування в області приварювання має глибинний характер. При такому вигляді міцнісного зв'язку пресовані суміші можуть мати значну міцність як на стиснення, так і на розтяг.

Зв'язок за рахунок контактного налипання металевих частинок також забезпечує відносно високу міцність спресованої суміші.

Міцнісні зв'язки, що виникають при взаємодії частинок метал - окиснювач або окиснювач - окиснювач, обумовлюються контактним налипанням i визначаються, головним чином, міцнісними характеристиками окиснювача. Міцність такого зв'язку може бути більшменш значною тільки на стиснення.

Таким чином, найбільш сильними $\epsilon$ зв'язки, що виникають на окремих контактах суміжних частинок металевого порошкоподібного компонента. При значному вмісті металевого порошку у суміші її міцність визначається зв'язками між частинками металу, при малому - між частинками окиснювача.

Висновки. В результаті проведених досліджень пожежної безпеки піротехнічних нітратно-металевих сумішей отримано наступні результати:

1. Порушення міцності поверхневих шарів зразків сумішей призводить до передчасного пожежовибухонебезпечного спрацьовування виробів на їх основі в умовах зовнішніх термічних дій.

2. Встановлено нові закономірності впливу технологічних параметрів зразків сумішей на їх міцність:

- міцність зразків на розтяг нижча у напрямку пресування, а їх міцність на стиснення в цьому напрямку вища;

- межа міцності зразків на стиснення $\sigma_{n}^{c m}$ (Па) зростає 3 підвищенням тиску $P$ (Па), а залежність $\sigma_{n}^{c m}=f(P)$ змінюється від експоненціального характеру до лінійного;

- коефіцієнт ущільнення сумішей та їх міцність $є$ незалежними характеристиками: менш густа пресована суміш може бути більш міцною, та навпаки; 
- при збільшенні вмісту порошку металу в суміші міцність іiї зразків монотонно зростає, прямуючи до одного й того ж граничного значення;

- 3 підвищенням температури нагріву суміші від 213 К до 333 К, незалежно від вмісту в ній титану, природи окиснювача та коефіцієнта ущільнення, міцність їі зразків зменшується; при цьому зі зменшенням вмісту окиснювача ступінь впливу температури нагріву послаблюється;

- ступінь збільшення міцності зразків сумішей зі зміною дисперсності порошку титану практично не залежить від природи окиснювача: для сумішей $\mathrm{Ti}+\mathrm{NaNO}_{3} \mathrm{i} \mathrm{Ti}+$ $\mathrm{Ba}\left(\mathrm{NO}_{3}\right)_{2}$ при збільшенні дисперсності порошку титану від 45 мкм до 250 мкм міцність їх зразків зменшується в $1,4 \ldots 1,6$ разу;

- підвищення міцності зразків зазначених сумішей при зменшенні дисперсності окиснювача від 250 мкм до 45 мкм також практично однакове: для суміші $\mathrm{Ti}+\mathrm{NaNO}_{3}-$ в 1,3 разу, а для суміші $\mathrm{Ti}+\mathrm{Ba}\left(\mathrm{NO}_{3}\right)_{2}-$ в 1,4 разу;

- органічні добавки за ступенем їх впливу на підвищення міцності зразків сумішей розташовуються у ряд: бутилкаучук > тіокол $>$ нітроплівка + смола $214>$ смола 214 $>$ фторкаучук СКФ - $32>$ нітроплівка $>$ фторопласт 32 Л $>$ ідітол $>$ гексахлорпараксілол $>$ полівінілхлорид;

- при підвищенні тиску пресування, зниженні висоти пресування, збільшенні часу витримки, застосуванні двостороннього пресування міцність зразків сумішей збільшується;

- при перепресуванні сумішей (підвищення тиску пресування до значень $10^{9} \ldots 2 \cdot 10^{9}$ Па) ані істотного зміцнення, ані розупорядкування суміші не відбувається порівняно з сумішшю, отриманою при тиску, при якому досягається максимальна густина.

\section{Список літератури}

[1] К. О. Брауэр, "Пиротехнические устройства для космических аппаратов", Вопросы ракетной техники, вып. 10, с. 47-61, 1969.

[2] Вспомогательные системы ракетнокосмической техники, пер. с англ., И. В. Тишунин, ред. - Москва: Мир, 1970.
[3] В. В. Тарасов, и Ю. Г. Якушенков, "Инфракрасные системы "смотрящего" ти$n a "$. Москва: Логос, 2004.

[4] А. Р. Глущенко, $\quad$ В. И. Гордиенко, А. В. Бурак, и А. Ю. Денисенко, Танковые ночные системы и приборы наблюдения. Черкассы: Фотоприбор, 2007.

[5] А. А. Шидловский, А. И. Сидоров, и В. М. Антонов, "Искусство управления огнем", Наука и жизнь, вып. 6, с. 82, 1971.

[6] А. А. Шидловский, Основы пиротехники. Москва: Машиностроение, 1973.

[7] А. А. Шидловский, А. И. Сидоров, и Н. А. Силин, Пиротехника в народном хозяйстве. Москва: Машиностроение, 1978.

[8] Н. А. Силин, В. А. Ващенко, Л. Я. Кашпоров и др., Металлические горючие гетерогенных конденсированных систем. Москва: Машиностроение, 1976.

[9] Н. А. Силин, В. А. Ващенко, Н. И. Зарипов и др., Окислители гетерогенных конденсированных систем. Москва: Машиностроение, 1978.

[10] Н. А. Силин, В. А. Ващенко, Л. Я. Кашпоров и др., Горение металлизированных гетерогенных конденсированных систем. Москва: Машиностроение, 1982.

[11] В. А. Ващенко, О. В. Кириченко, Ю. Г. Лега, П. И. Заика, И. В. Яценко, и В. В. Цыбулин, Проиессы горения металлизированных конденсированных систем. Киев: Наукова думка, 2008.

[12] О. В. Кириченко, "Повышение эффективности пиротехнических нитратосодержащих изделий в условиях их применения", Вісник Черкаського державного технологічного університету, № 2, с. 8994, 2009 (Технічні науки).

[13] О. В. Кириченко, "Скорость и предельные режимы горения трехкомпонентных пиротехнических смесей в условиях внешних термовоздействий", Пожаровзрывобезопасность: междунар. науч.практ. журн., № 5, с. 20-25, Москва: Пожнаука, 2013.

[14] О. В. Кириченко, "Влияние повышенных температур нагрева и внешних давлений на скорость и предельные режимы горения пиротехнических нитратноалюминиевых смесей", Чрезвычайные ситуащии: промышленная и экологическая 
безопасность: междунар. науч.-практ. журн., № 2, Краснодар: Кубан. соц.-экон. ин-т, 2013.

[15] О. В. Кириченко, "Тепловые воздействия на поверхность металлических обтекателей пиротехнических изделий в условиях выстрела и полета", Пожаровзрывобезопасность: междунар. науч.-практ. журн., № 9, с. 6-11, Москва: Пожнаука, 2013.

[16] О. В. Кириченко, "Моделирование процесса нагрева металлических оболочек пиротехнических изделий в условиях внешних термовоздействий", Чрезвычайные ситуации: образование и наука: междунар. науч.-практ. журн., № 2, с. 3745, Гомель: Гомель. инж. ин-т, 2013.

[17] О. В. Кириченко, "Экспериментальностатические модели для прогнозирования влияния внешних термовоздействий на скорость горения пиротехнических смесей", Вестник КИИ, № 2 (18), с. 35-41, Минск: КИИ МЧС РБ, 2013.

[18] О. В. Кириченко, В. А. Ващенко, та В. В. Цибулін, "Пожежонебезпечні термовпливи на поверхню металевих корпусів піротехнічних виробів в умовах пострілу та польоту", Проблемы пожарной безопасности, № 32, с. 98-112, Харьков: НУГЗУ, 2012.

[19] О. В. Кириченко, П. С. Пашковський, В. А. Ващенко, та Ю.Г. Лега, Основи пожежної безпеки піротехнічних нітратовмісних виробів в умовах зовнішніх термовпливів: монографія. Київ: Наук. думка, 2012.

[20] Л. П. Вогман, и О. В. Сотников, "Нормирование пожарной опасности фейерверочных пиротехнических изделий бытового назначения", Пожаровзрывобезопасность, № 2, с. 3-11, 1998.

[21] Л. П. Вогман, и В. В. Лепесий, "Требования пожарной безопасности к пиротехническим изделиям бытового назначения", Пожаровзрывобезопасность, № 4, c. 51-57, 1998.

[22] Л. П. Вогман, В. А. Зуйков, В. Е. Татаров, и В. В. Лепесий, "Разработка рекомендаций по обеспечению пожарной безопасности фейерверочных пиротехнических изделий", Пожаровзрывобезопасность, № 3, с. 24-41, 2002.
[23] ГОСТ Р 51271 - 99. Изделия пиротехнические. Методы сертификационных испытаний.

[24] ГОСТ Р 51270 - 2000. Изделия пиротехнические. Общие требования безопасности.

[25] Г. Н. Кириллов и др., Требования пожарной безопасности при обращении пиротехнической продукции: обзорно-аналит. материал. Москва: ВНИИПО и ДНД МЧС России, 2010.

[26] СТО 4. 3. 1 - 2003. Изделия пиротехнические. Правила безопасности при обращении с пиротехнической продукцией. Сергиев-Посад: Ассоциация "Рапидфейерверк", 2013.

\section{References}

[1] K. O. Brower, "Pyrotechnic devices for spacecraft", Voprosy raketnoi techniki, iss. 10, pp. 47-61, 1969 [in Russian].

[2] Support systems of rocket and space technology, transl. from Engl., I. V. Tishunin, Ed. Moscow: Mir, 1970 [in Russian].

[3] V. V. Tarasov, and Yu. G. Yakushenkov, "Looking" type infrared systems. Moscow: Logos, 2004 [in Russian].

[4] A. R. Glushchenko, V. I. Gordienko, A. V. Burak, and A. Yu. Denisenko, Tank night systems and surveillance devices. Cherkassy: Fotopribor, 2007 [in Russian].

[5] A. A. Shidlovskii, A. I. Sidorov, and V. M. Antonov, "The art of fire control", Nauka i zhizn, iss. 6., p. 82, 1971 [in Russian].

[6] A. A. Shidlovskii, Bases of pyrotechnics. Moscow: Mashinostroenie, 1973 [in Russian].

[7] A. A. Shidlovskii, A. I. Sidorov, and N. A. Silin, Pyrotechnics in the national economy. Moscow: Mashinostroenie, 1978 [in Russian].

[8] N. A. Silin, V. A. Vaschenko, and L. Ya. Kashporov, Metal fuels of heterogeneous condensed systems. Moscow: Mashinostroenie, 1976 [in Russian].

[9] N. A. Silin, V. A. Vashchenko, and N. I. Zaripov, Oxidizers of heterogeneous condensed systems. Moscow: Mashinostroenie, 1978 [in Russian]. 
[10] N. A. Silin, V. A. Vaschenko, and L. Ya. Kashporov, Combustion of metalized heterogeneous condensed systems. Moscow: Mashinostroenie, 1982 [in Russian].

[11] V. A. Vashchenko, O. V. Kirichenko, Yu. G. Lega, P. I. Zaika, I. V. Yatsenko, and V.V. Tsybulin, Combustion processes of metallized condensed systems. Kyiv: Nauk. dumka, 2008 [in Russian].

[12] O. V. Kirichenko, "Improvement of the efficiency of pyrotechnic nitrate-containing products under conditions of their use", Visnyk Cherkaskogo derzhavnogo tehnologichnogo universitetu, no. 2, pp. 8994, 2009 [in Russian].

[13] O. V. Kirichenko, "The speed and limiting burning regimes of three-component pyrotechnic mixtures under external thermal impact conditions", Pozharovzryvobezopasnost, no. 5, pp. 20-25, 2013 [in Russian].

[14] O. V. Kirichenko, "The effect of elevated heating temperatures and external pressures on the rate and limiting modes of combustion of pyrotechnic nitrate-aluminum mixtures", Chrezvychainye situatsii: promyshlennaya i ekologicheskaya bezopasnost, no. 2, 2013 [in Russian].

[15] O. V. Kirichenko, "Thermal effects on the surface of metal fairings of pyrotechnic products in the conditions of a shot and flight", Pozharovzryvobezopasnost, no. 9, pp. 6-11, 2013 [in Russian].

[16] O. V. Kirichenko, "Simulation of the heating process of metal shells of pyrotechnic products under external thermal influences", Chrezvychainye situatsii: obrazovanie $i$ nauka, no. 2, pp. 37-45, 2013 [in Russian].

[17] O. V. Kirichenko, "Experimental statistic models for predicting the impact of external thermal effects on the burning rate of pyrotechnic mixtures", Vestnik KII, no. 2 (18), pp. 35-41, 2013 [in Russian].
[18] O. V. Kirichenko. V. A. Vashchenko, and V. V. Tsibulin, "Firefighting thermoinfluences on the surface of metal shells of pyrotechnic articles in the conditions of a shot and a flight", Problemy pozharnoi bezopasnosti, no. 32, pp.98-112, 2012 [in Ukrainian].

[19] O. V. Kirichenko, P. S. Pashkovsky, V. A. Vaschenko, and Yu. G. Lega, The bases of fire safety of pyrotechnic nitratecontaining products in the conditions of external thermal influences. Kyiv: Nauk. dumka, 2012 [in Ukrainian].

[20] L. P. Vogman, and O. V. Sotnikov, "Rationing of fire danger of fireworks pyrotechnic products for domestic use". Pozharovzryvobezopasnost, no. 2, pp. 3-11, 1998 [in Russian].

[21] L. P. Vogman, and V. V. Lepesii, "Fire safety requirements to pyrotechnic household products", Pozharovzryvobezopasnost, no. 4, pp. 51-57, 1998 [in Russian].

[22] L. P. Vogman, V. A. Zuykov, V. E. Tatarov, and V. V. Lepesii, "Development of recommendations for ensuring fire safety of fireworks pyrotechnic products", Pozharovzryvobezopasnost, no. 3, pp. 24-41, 2002 [in Russian].

[23] GOST R 51271 - 99. Pyrotechnic products. Methods of certification tests [in Russian].

[24] GOST R 51270 - 2000. Pyrotechnic products. General safety requirements [in Russian].

[25] G. N. Kirillov et al., Fire safety requirements when handling pyrotechnic products. Moscow: VNIIPO i DND MChS Rossii, 2010 [in Russian].

[26] SRT 4. 3. 1 - 2003. Pyrotechnic products. Safety rules when handling pyrotechnic products. Sergiev-posad: Rapid-feerverk, 2013 [in Russian]. 
O. V. Kirichenko ${ }^{1}$, Dr. Tech. Sc., senior scientist, head of the department of fire prevention work, e-mail: okskir@meta.ua

O. S. Dibrova ${ }^{2}$, postgraduate,

R. B. Motrichuk ${ }^{1}$, postgraduate,

V. A. Vaschenko ${ }^{3}$, Dr. Tech. Sc., professor, head of the department of physics and applied material science,

S. O. Kolinko ${ }^{3}$, Ph. D., associate professor of the department of physics and applied material science,

V. V. Tsybulin ${ }^{3}$, lecturer of the department of physics and applied material science

${ }^{1}$ Cherkasy Chornobyl Heroes Institute of Fire Safety

Onoprienko str., 8, Cherkasy, 18034, Ukraine

${ }^{2}$ National University of Civil Defense of Ukraine

Chernycshevskyi str., 94, Kharkiv, 61023, Ukraine

${ }^{3}$ Cherkasy State Technological University

Shevchenko blvd, 460, Cherkasy, 18006, Ukraine

\section{INVESTIGATION OF THE INFLUENCE OF STRENGTH OF CHARGES OF PYROTECHNIC NITRATE-METAL MIXTURES ON FIRE SAFETY OF PRODUCTS ON THEIR BASIS}

As a result of the conducted experimental researches it is established that the breaking of the strength of surface layers of pyrotechnic nitrate-metal mixtures leads to premature fire and explosive action of products on their basis in the conditions of external thermal influences. New data on the influence of technological parameters of mixture samples (the ratio and dispersion of components, the coefficient of their compaction, the nature of nitrate-containing oxidizer and organic additive, the pressure and compression direction, cure time, height and diameter of samples) on the limit of their strength are obtained. The tensile strength of the specimens is lower in the compression direction and their compressive strength is higher in this direction. The coefficient of compaction of the mixtures and their strength are independent characteristics: less dense pressed mixture may be more durable, and vice versa. As the content of the metal powder in the mixture increases, the strength of its samples increases monotonically, moving to the same limit value. With increasing the temperature of the mixture from $213 \mathrm{~K}$ to $333 \mathrm{~K}$, regardless of the content of titanium, the nature of the oxidizer and the coefficient of compaction, the strength of its samples decreases; the degree of influence of the heating temperature decreases as the oxidant content decreases. The degree of the increase in the strength of samples of mixtures with a change in the dispersion of titanium powder practically does not depend on the nature of the oxidizer: for mixtures of $\mathrm{Ti}+\mathrm{NaNO}_{3}$ and $\mathrm{Ti}+\mathrm{Ba}\left(\mathrm{NO}_{3}\right)_{2}$ with increasing the dispersion of titanium powder from $45 \mu \mathrm{m}$ to $250 \mu \mathrm{m}$, the strength of their samples decreases in 1,4 ... 1,6 times. Increasing the strength of the samples of these mixtures while reducing the dispersion of the oxidizer from $250 \mu \mathrm{m}$ to $45 \mu \mathrm{m}$ is also almost the same: for the mixture of $\mathrm{Ti}+\mathrm{NaNO}_{3}-1,3$ times, and for the mixture of $\mathrm{Ti}+\mathrm{Ba}\left(\mathrm{NO}_{3}\right)_{2}-1,4$ times.

Keywords: pyrotechnic mixture, strength, fire safety.

Стаття надійшла 09.08.2019

Прийнято 06.09.2019

() О. В. Кириченко, О. С. Діброва, Р. Б. Мотрічук, В. А. Ващенко, С. О. Колінько, В. В. Цибулін, 2019 DOI: 10.24025/2306-4412.3.2019.176874 